Review

\title{
The spiritual sense, prayer and traditional American Indian healing
}

\author{
James David Adams Jr., Cecilia Garcia \\ Department of Pharmacology and Pharmaceutical Sciences, School of Pharmacy, University of Southern California, USA
}

\begin{abstract}
A spiritual sense may be present in the human brain. Demonstration of the spiritual sense depends on measuring the behavioral effects of spiritual experiences. These experiences can be induced by prayer, specific chemicals and other stimuli that are known to interact with pyramidal neurons of layer 5 in the cerebral cortex. This work examines the hypothesis that pyramidal neurons are the seat of the spiritual sense. Healers use the spiritual sense to comfort and heal their patients, especially with prayer. Many doctors do not encourage prayer and could learn from healers to use the spiritual sense. Patients should be educated to use prayer in order to get the comfort they need for healing.
\end{abstract}

Keywords spiritual sense, pyramidal neurons, healing

\section{A scientific basis for measuring spirituality - the hypothesis}

Traditional American Indian healing begins with prayer (Garcia et al., 2009; Adams et al., 2005b) since healers believe that all healing must begin with God (Garcia et al., 2009; Kavasch et al., 1999; Buhner, 1996). Prayer can be used to stimulate the spiritual sense. However, modern medicine does not recognize a spiritual sense that may be invoked during healing. In fact, prayer and comfort are usually referred to as placebos, that some investigators believe should be avoided in the clinical setting (Oken, 2008). Prayer has been studied extensively in clinical studies and has been shown to be safe in all settings (Astin et al., 2000). Prayer comforts patients and helps them to be calm during times when difficult healthcare decisions must be made. In addition, an awareness of God has been shown, in functional magnetic resonance imaging experiments, to be beneficial to patients (Newberg et al., 2010).

The medical hypothesis of the current work is that the spiritual sense can be used in healing. This article explores the possibility of a spiritual sense that is used by traditional American Indian and other healers and could be used by doctors.

The spiritual sense is a sense like sight, smell, hearing, taste, and touch. It gives feelings of conscience, right and wrong, good and bad, comfort, inspiration, creativity and compassion. The spiritual sense is distinct from common sense. Common sense teaches us to protect ourselves from potentially harmful situations and to seek beneficial situations. The spiritual sense provides complex feelings that are not well understood scientifically. The neurons and biochemical processes involved in the spiritual sense are currently not completely understood. The spiritual sense, like any other sense, must be learned and fostered. Like any other sense, some people are more endowed with the spiritual sense than others. The current work provides a basis for examining the neurons and the biochemistry of the spiritual sense.

${ }^{*}$ Correspondence: James David Adams Jr.

E-mail: jadams@pharmacy.usc.edu

Received June 15, 2011; Accepted February 13, 2012; Published

February 29, 2012

doi: http://dx.doi.org/10.5667/tang.2011.0012

C 2012 by Association of Humanitas Medicine
A spiritual sense is a central theme in Christianity. Christians believe that the Holy Spirit, an alternate form of God, is present in all of us and gives us a sense of right and wrong. In the Hindu faith, it is believed that we all carry a part of Brahman in our hearts. Among Buddhists, compassion, a component of the sense of right and wrong, is essential to human existence (Dalai Lama, 1996). A spiritual sense is a theme in several religions.

Many people undergo spiritual experiences every day. These spiritual experiences are elicited by the spiritual sense. Some of these spiritual experiences are stimulated by prayer, psychoactive substances, plant preparations, meditative states and other influences. The behavioral effects of spiritual experiences can be easily measured scientifically, since they cause changes in personality and personal charity (Griffiths et al., 2006). The Reverend Robert Cromy provides two tests of religious experiences (Smith et al., 1967): does the experience make a man more human; and does the experience make a man more loving and serving? For instance, a person who has just passed through a spiritual experience may become more giving with monetary donations and volunteer work for charitable organizations (Griffiths et al., 2006). There may also be positive changes in personality that reflect a more giving personality (Griffiths et al., 2006; McNamara et al., 2006). Spiritual experiences frequently stimulate people to find more time to worship (Griffiths et al., 2006), to be calm (Newberg et al., 2010) and perhaps to develop social networks. Larger social networks, among women, are associated with lower mortality rates from coronary artery disease (Rutledge et al., 2004). These changes brought about by spiritual experiences can be beneficial to health and healing (McNamara et al., 2006; Newberg et al., 2010).

\section{Chemicals that stimulate the spiritual sense}

Many plant derived chemicals can stimulate the spiritual sense and elicit spiritual experiences (Fig. 1). For instance, peyote, Lophophora williamsii, has been used for thousands of years by American Indians to induce spiritual experiences (El-Seedi et al., 2005; Nichols et al., 2006). Similarly, Psilocybe mushrooms have been used by many people around the world since prehistoric times for spiritual experiences (Wasson, 1980). Datura plants, especially Datura wrightii, have been used to 
induce spiritual experiences and for rites of passage by American Indians (Garcia et al., 2009). Tobacco, such as Nicotiana attenuata, has been used by Cahuilla and other American Indians for spiritual experiences and for rites of passage (Garcia et al., 2009). Salvia divinorum, that contains salvinorin A, is the way to God for Mazatec people who use the plant for sacred dreams (Li et al., 2007). Morning glory seeds from Ipomoea tricolor and I. corymbosa contain the ergot alkaloids, ergonovine and ergine, and are used for sacred dreams (Hofman, 1971). Red harvester ants, Pogonomyrmex californicus, have been used for spiritual experiences and for rites of passage by Chumash and other American Indians (Garcia et al., 2009). About 250 ants were ingested alive in order to allow the ants to sting the inside of the mouth and throat. The venom from the ants appears to contain nicotinic kinins (Piek, 1990) that are proteins that interact with nicotinic acetylcholine receptors (NAChR). Kinetic activities can also induce spiritual experiences, such as the whirling dervishes and similar activities (Al-Krenawi et al., 1996). These kinetic activities are known to stimulate the release of endorphins and enkephalins (Radosevich et al., 1989).

Mescaline from peyote interacts with serotonin receptors, especially $5-\mathrm{HT}_{2 \mathrm{~A}}$ and 5$\mathrm{HT}_{2 \mathrm{C}}$ receptors in the brain (Monte et al., 1997; Appel et al., 1989). Psilocybin, from Psilocybe mushrooms, interacts with $5-\mathrm{HT}_{2 \mathrm{~A} / \mathrm{C}}$ receptors also (Appel et al., 1989). In fact there are a number of spiritual compounds that interact with $5-\mathrm{HT}_{2 \mathrm{~A} / \mathrm{C}}$ receptors, including ergot alklaloids, lysergic acid diethylamide (LSD), $\mathrm{N}, \mathrm{N}$-dimethyltryptamine from ayahuasca, and 2,5-dimethoxy-4-methylamphetamine (Appel et al., 1989; Riba, 2002). Scopolamine, from Datura plants, interacts with muscarinic acetylcholine receptors (MAChR) in the brain (Dringenberg et al., 2004). Nicotine from tobacco interacts with NAChR in the brain (Alkondon et al., 2004). Nicotinic kinins may interact with NAChR also. Salvinorin A from Salvia divinorum interacts with kappa opioid receptors (KOR) (Li et al., 2007). Endorphins and enkephalins, from kinetic activities, interact with mu opioid receptors (MOR) in the brain (Marek et al., 1998).

Mescaline $\rightarrow$ Cerebral cortex $\rightarrow 5 \mathrm{HT}_{2 \mathrm{~A} / \mathrm{C}}$ receptors $\rightarrow$ Pyramidal neurons

Scopolamine $\rightarrow$ Striatum $\rightarrow$ MAChR $\rightarrow$ Pyramidal neurons

Nicotine $\rightarrow$ Cerebral cortex $\rightarrow$ NAChR $\rightarrow$ Pyramidal neurons

Salvinorin A $\rightarrow$ Cerebral cortex $\rightarrow$ KOR $\rightarrow$ Pyramidal neurons

Opioids $\rightarrow$ Cerebral cortex $\rightarrow$ MOR $\rightarrow$ Pyramidal neurons

There are a variety of chemicals that interact with several receptors to invoke spiritual experiences. How do all of these chemicals invoke the same kind of experience? They all

TANG / www.e-tang.org<smiles>CN1CC(C(N)=O)C=C2c3cccc4[nH]cc(c34)C[C@H]21</smiles>

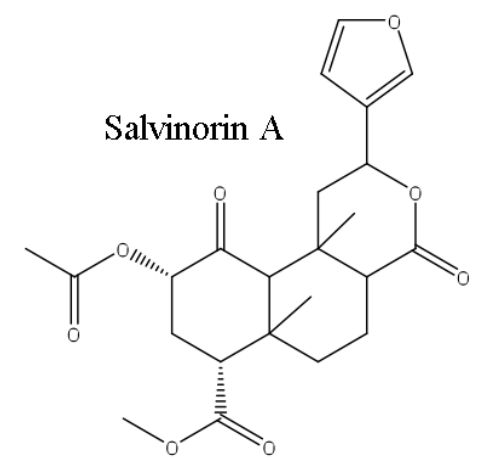

Lysergic acid amide, ergine

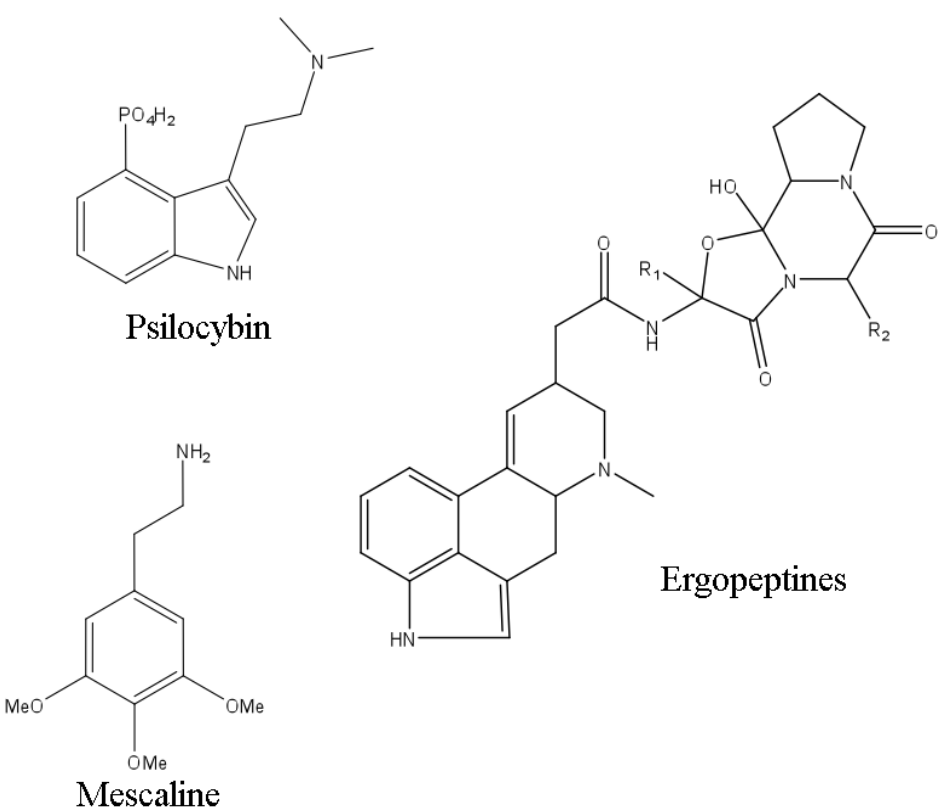<smiles>CN1C2CC(OC(=O)C(CO)c3ccccc3)CC1C1OC12</smiles><smiles>CN1CCCC1c1cccnc1</smiles>

Nicotine

Scopolamine<smiles>CCC1CC2c3[nH]c4ccc(OC)cc4c3CCN3CC(CC)C(C1)C23</smiles>

Ibogaine<smiles>CN(C)CCc1c[nH]c2ccccc12</smiles>

Dimethyltryptamine

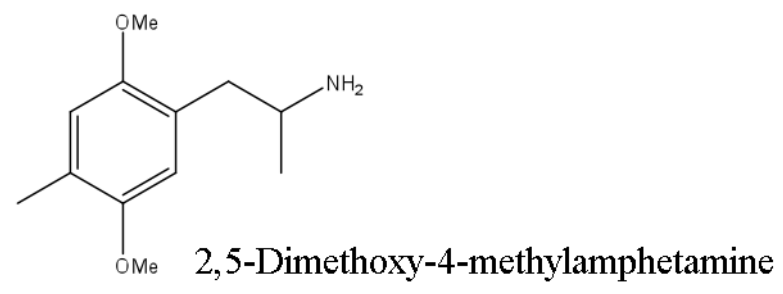

Fig. 1. Spiritual Chemicals. 


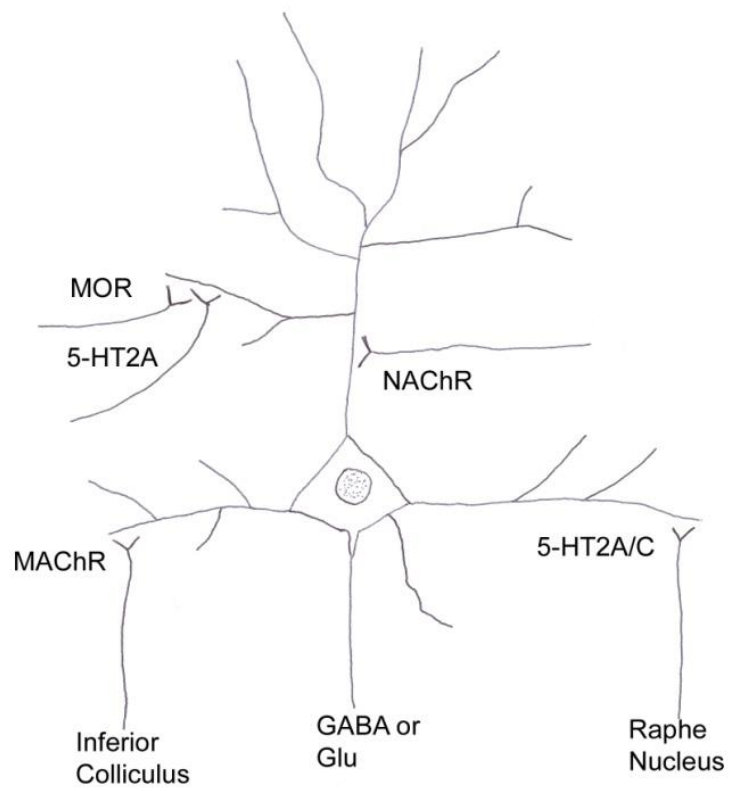

Fig. 2. Pyramidal neuron in layer 5 of the cerebral cortex.

produce direct or indirect effects in the same cells, the pyramidal neurons of layer 5 in the cerebral cortex.

\section{Pyramidal neurons as the basis of the spiritual sense}

Pyramidal neurons in the cerebral cortex are involved in learning, memory (Sjostrom et al., 2006) and prayer. Pyramidal neurons in the amygdala are involved in emotion, pain and memories (Faber et al., 2004), and could be indirectly, or negatively, involved in the spiritual sense. Pyramidal neurons in the cerebral cortex are either glutamatergic or gammaaminobutyric acidergic (Alkondon et al., 2004; Marek et al., 1998). Each neuron has a short axon and a huge array of dendrites (Fig. 2). These dendrites interact with many other neurons from other parts of the brain and with interneurons from the cerebral cortex. Dendritic input to the pyramidal cell soma is very plastic, and can switch from long term potentiation to long term depression depending on global summation (Sjostrom et al., 2006; Polsky et al., 2004). This plasticity implies that inhibitory and excitatory inputs may have the same effects on pyramidal neurons, as determined by switching.

Cortical pyramidal neurons receive input from neurons in the midbrain inferior colliculus through MAChR mediated synapses (Dringenberg et al., 2004; Dringenberg et al., 2006). Striatal cholinergic interneurons provide cholinergic input through muscarinic type 1 (M1) receptors to striatal spiny neurons that synapse with cortical pyramidal neurons (Wang et al., 2006; Zhang et al., 2006). In fact, layer 5 of the cerebral cortex contains M1, M2, M3, M4 and M5 receptors (Tayebati et al., 2006). These receptors may be where scopolamine from Datura plants interacts. Input from the brain stem Raphe nucleus to pyramidal neurons in the cerebral cortex occurs through 5- $\mathrm{HT}_{2 \mathrm{~A} / \mathrm{C}}$ synapses (Dringenberg et al., 2004). This may be where psilocybin, mescaline, ergot alkaloids, LSD and other compounds interact with pyramidal neurons. Cererbral cortex interneurons provide NAChR and opioid, especially MOR and perhaps KOR, input to pyramidal neurons (Marek et al., 1998). These receptors may be where nicotine, salvinorin A and endogenous opioids interact with the neurons. It appears that the pyramidal neurons of layer 5 of the cerebral cortex are an important site of action of all of the spiritual compounds in Fig. 1. Pyramidal neurons may sense this spiritual input. This implies that humans have an ability to sense the spiritual, in other words a spiritual sense.

Cerebral cortex pyramidal neurons receive input from the striatum, mibrain, brain stem and other brain regions. All of these inputs modify the signals going into and out of the pyramidal neurons. This modification is highly complex.

\section{Hallucinations versus sacred dreams}

Volitional aspects of pyramidal neurons appear to be very important in learning, memory and spiritual experiences. Among Chumash and other American Indians, careful education occurred prior to the induction of spiritual experiences, called sacred dreams, in order to prepare individuals to receive the experiences (Garcia et al., 2009; Adams et al., 2005b). Our current society has few healers who can educate people in how to use sacred dreams as a way to God.

Among Buddhists, sacred dreams are induced by meditation. Kinetic activity is used to induce sacred dreams among many people including people from India and Arabs. Fasting is another way of inducing sacred dreams.

Many people use spiritual chemicals even when they are not properly prepared to receive sacred dreams. There are many reports of delirium and psychosis induced by LSD, psilocybin, mescaline and other compounds (Nichols, 2004; Vollenweider et al., 1999). In addition, recreational or hedonistic use of spiritual compounds is well known in our society (Shulgin et al., 1991). It is clear that pyramidal neurons are plastic enough to provide different experiences depending on the education or expectations of the individual. It is also possible that the dose of the spiritual chemical is important in determining the nature of the experience, spiritual, hedonistic or psychotic.

The normal sacred dream experience for Chumash and other American Indians is only performed a few times, such as four times during a lifetime with Datura wrightii. The purpose of these spiritual experiences is to help the person with difficult decisions, such as the choice to become an adult with a profession, the choice of a spouse, the choice to have a child and the choice to die. These spiritual experiences are seen as a powerful way to talk to God. Spiritual experiences are sought in order to make decisions about accepting more responsibility, such as accepting a spouse or a child. These experiences are not escapes from reality.

There are several reports of people seeking spiritual experiences that result in multiple treatments, such as with ayahuasca (Salak, 2006). These multiple treatments are performed to restore a normal personality (exorcise dangerous spirits) to the person. Someone with a normal personality should never use spiritual plants multiple times.

There are many medically described hallucinations that may not include spiritual components. Hallucinations induced by dopamine agonists such as bromocriptine or levodopa have not been described as spiritual. However, Parkinson's disease patients, who have low brain dopamine levels, are less religious than controls (McNamara et al., 2006). This implies that the dopaminergic system may be involved in religious beliefs. Alcohol withdrawal can involve hallucinations that may not be spiritual. Starvation, sensory deprivation and extreme stress can induce hallucinations that have not been described as spiritual. Ketamine and phencyclidine induce a dissociative state that has not been referred to as spiritual. Psychosis and dementia can involve hallucinations that may be described as spiritual, but may not be a positive or comforting influence for the individual. 
There are many mechanisms of hallucination induction, most of which may not invoke positive spiritual experiences. It appears that mechanisms involving dopamine release or stimulation of dopamine receptors lead mostly to hedonistic or psychotic responses and less to spiritual responses (Vollenweider et al., 1999).

In general, hallucinations leave patients confused. Sacred dreams can provide comfort and guidance. Hallucinations may lead to isolation and escape from responsibility. Sacred dreams may lead to more social interactions, a larger social group and the acceptance of more responsibility. The difference between the induction of hallucinations and sacred dreams is education and proper use of the plants.

\section{Normal sacred dreams}

In the American Indian tradition, when a child is ready to decide whether or not to become an adult and to accept a profession, the spiritual leaders begin to prepare the child and the family a year in advance of the actual spiritual experience. The sacred dream is sought in order to help the child accept the responsibility of becoming an adult and to help the child find a profession. The ceremony lasts four days. The first day prepares the child to dream. The adults sing lullabies for the child. The vigil then begins with the lighting of the fire that must burn without cease during the four days. The spiritual leaders stand vigil with the child and observe as the child starts to have a sacred dream. The dream may last as long as 2 days, depending on the spiritual plant used. All spiritual plants have dangers that must be watched for, such as vomiting, respiratory depression, seizures and other possibilities. Some of the children do not survive the sacred dream, which indicates an inability of the child to accept the responsibility of adulthood. The third day is a day of recovery when the child is counseled by spiritual leaders who help the child interpret the sacred dream. The fourth day is a welcoming time, when the child begins the journey toward adulthood and accepts the responsibility to learn a profession.

Other times that plant induced sacred dreams are sought are when an adult must make the decision to accept more responsibility, such as the responsibility of a spouse, a child or the time to die. The plant preparations used are milder at these times, because the adult has already earned a place in society and does not need to be challenged again.

Prayer can always be used as a means of seeking answers to difficult questions, such as should a patient undergo chemotherapy or not; should a patient have surgery or not? These are difficult and frightening questions that many patients cannot answer easily. Prayer can provide comfort and the objectivity needed to find a reasonable answer to difficult questions. Group prayer provides a social network to support and comfort the patient. A strong social network can help the patient with difficult decisions.

\section{Dangers of spiritual chemicals}

There are several reports of people using LSD and other psychoactive chemicals, who do not have sacred experiences. Perhaps they were not prepared or had poorly developed spiritual senses. As noted above, inappropriate use of any spiritual chemical sometimes results in psychosis that usually resolves as the chemical is cleared from the body. Flashbacks, involving recall of psychotic drug induced experiences, can also occur (Nichols, 2004; Roberts, 2006). In terms of depressant drugs, high doses can cause hallucinations. A higher dose causes coma. A yet higher dose causes death. Scopolamine overdose can be fatal, due to respiratory depression (Garcia et al., 2009). Nicotine overdose can be fatal, due to vomiting, seizures and respiratory depression (Garcia et al., 2009). Mescaline can cause fatality through vomiting and aspiration (Nolte et al., 1999). Salvinorin A is a KOR and dopamine receptor type 2 (D2) agonist (Li et al., 2007; Seeman et al., 2009). KOR agonists, such as enadoline, can induce locomotor impairment and psychotomimetic effects that could be life threatening (Walsh et al., 2001). Many spiritual chemicals have been used in rites of passage when a child became an adult. These rites of passage were sometimes fatal (Garcia et al., 2009). However, rites of passage were considered essential to the wellbeing of many communities. Because they provided intense spiritual experiences that helped children mature into adults with strong spiritual senses.

\section{Functions of the spiritual sense}

How do healers use the spiritual sense to facilitate healing? The spiritual sense provides comfort and intuition that is vital to healing (Garcia et al., 2009; Adams et al., 2005b). Comfort allows patients to rest, sleep, dream and heal. These spiritual experiences are not the intense spiritual experiences associated with rites of passage and are induced by prayer. In addition, the spiritual sense may allow some patients to gain a new perspective on their problems (Roberts, 2006), thereby providing comfort. There are reports of miraculous cures that may be brought about by prayer or spiritual experiences. There is no doubt that terminally ill patients do sometimes recover against all odds. It is not known how the spiritual sense may function in these cases. Stimulation of the spiritual sense by prayer also has been used by healers to help recovering patients or young adults find their place in society and become contributing members of society (Adams et al., 2005b). Of course, a patient at the end of life may become frightened due to the dread of the unknown, which may be a negative effect of the spiritual sense. It is the task of the healer to comfort the patient and help the patient see the positive aspects of the spiritual sense. This comfort is an important part of palliative care (Adams et al., 2005a).

Creativity may be another vital function of the spiritual sense. A healer is sometimes confronted with a disease that does not respond to conventional therapy. The healer must go into the wild and find a new cure. This is done by fasting, praying and spending as much as four nights sleeping among the plants that may provide useful therapy (Garcia et al., 2009). The healer is guided by intuition and prayer induced sacred dreams that come from the spiritual sense in this creative process.

\section{CONCLUSIONS}

It is widely believed among American Indians and others that all people have a spiritual sense (Garcia et al., 2009). This sense is essential for healing (Adams et al., 2005b). Healers in many areas use prayer induced stimulation of the spiritual sense to supposedly heal and to stimulate the spiritual wellbeing of their patients (Garcia et al., 2009; El-Seedi et al., 2005; Wasson, 1980; Al-Krenawi et al., 1996). Spiritual wellbeing has been a requirement for passage into adulthood among some American Indians (Garcia et al., 2009). Plant preparations have been used to induce spiritual experiences in these rites of passage. The spiritual sense of a patient can be invoked with simple, safe procedures such as prayer in order to facilitate healing. Spiritual experiences are frequently described as comforting or inspiring and invoke positive changes in the lives of the individuals involved (Garcia et al., 2009; Griffiths 
et al., 2006). It now appears that the scientific basis of spiritual experiences and the spiritual sense may reside in the stimulation of pyramidal neurons in the cerebral cortex.

It should be mentioned that the spiritual sense may not involve a belief in God by all people. For instance among some Chinese, knowing the Tao may be the basis of spirituality. Among Buddhists, finding Nirvana may be the basis of spirituality. Knowing the Tao or seeking Nirvana may involve the spiritual sense.

The pyramidal neurons in the cerebral cortex form a very diffuse and plastic network with interconnections throughout the brain. These neurons are involved in processing all the signals involved in learning and memory. Clearly, the intelligence of humans is a vital aspect of learning, memory, the spiritual sense and other functions of pyramidal neurons.

Endorphins and enkephalins are endogenous ligands made in the body, are released into the blood and produce distant effects on opioid neurons. It is not known if similar endogenous peptide ligands exist for serotonergic, muscarinic and nicotinic receptors. These endogenous peptide ligands may provide spiritual experiences for people during prayer, worship and healing.

American Indians use the spiritual sense as a way to God and in healing. The plants they use are protected by religious freedom laws. Trials could be conducted with American Indian healers in healthcare settings to look for possible benefits of educating patients about prayer, the spiritual sense and sacred dreams. Doctors could be educated in how to facilitate healing in their patients with the spiritual sense. Patients who are properly educated and who use these experiences properly could find comfort, a new point of view and better healing through these practices.

At this moment, there is no single explanation for spiritual experiences and the location of the spiritual sense. More studies are needed in order to evaluate the outcomes provided by American Traditional healers and the mechanisms of how this healing may work. The hypothesis presented in this work should be evaluated with caution.

\section{ACKNOWLEDGEMENTS}

The authors are grateful to Ted Garcia (former Chumash Elder) for reading and critiquing this manuscript.

\section{CONFLICT OF INTEREST}

The authors have no conflicting financial interests.

\section{REFERENCES}

Adams JD, Garcia C. Palliative care among Chumash people. Evid Based Complement Alternat Med. 2005;2:143-147.

Adams JD Jr, Garcia C. Spirit, mind and body in Chumash healing. Evid Based Complement Alternat Med. 2005;2:459463.

Alkondon M, Albuquerque EX. The nicotinic acetylcholine receptor subtypes and their function in the hippocampus and cerebral cortex. Prog Brain Res. 2004;145:109-120.

al-Krenawi A, Graham JR, Maoz B. The healing significance of the Negev's Bedouin Dervish. Soc Sci Med. 1996;43:13-21.
Appel JB, Callahan PM. Involvement of 5-HT receptor subtypes in the discriminative stimulus properties of mescaline. Eur J Pharmacol. 1989;159:41-46.

Astin JA, Harkness E, Ernst E. The efficacy of "distant healing": a systematic review of randomized trials. Ann Intern Med. 2000;132:903-910.

Buhner SH. Sacred Plant Medicine Explorations in the Practice of Indigenous Herbalism. (USA: Raven Press), 1996.

Kotler A. In engaged Buddhist reader ten years of engaged Buddhist publishing. (CA, USA: Parallax Press), pp. 3-6, 1996.

Dringenberg HC, Sparling JS, Frazer J, Murdoch J. Generalized cortex activation by the auditory midbrain: mediation by acetylcholine and subcortical relays. Exp Brain Res. 2006;174:114-123.

Dringenberg HC, Yahia N, Cirasuolo J, McKee D, Kuo MC. Neocortical activation by electrical and chemical stimulation of the rat inferior colliculus: intra-collicular mapping and neuropharmacological characterization. Exp Brain Res. 2004;154:461-469.

El-Seedi HR, De Smet PA, Beck O, Possnert G, Bruhn JG. Prehistoric peyote use: alkaloid analysis and radiocarbon dating of archaeological specimens of Lophophora from Texas. J Ethnopharmacol. 2005;101:238-242.

Faber ES, Sah P. Opioids inhibit lateral amygdala pyramidal neurons by enhancing a dendritic potassium current. J Neurosci. 2004;24:3031-3039.

Garcia C, Adams JD. Healing with medicinal plants of the West - cultural and scientific basis for their use. (La Crescenta: Abedus Press), 2009.

Griffiths RR, Richards WA, McCann U, Jesse R. Psilocybin can occasion mystical-type experiences having substantial and sustained personal meaning and spiritual significance. Psychopharmacol. 2006;18:268-283.

Hofmann A. Teonanacatl and Ololiuqui: Two ancient magic drugs of Mexico. Bull Narcotics. 1971;23:3-14.

Kavasch EB, Baar K. American Indian Healing Arts Herbs, Rituals, and Remedies for Every Season of Life. (New York, USA: Bantam), 1999.

Li Y, Husbands SM, Mahon MF, Traynor JR, Rowan MG. Isolation and chemical modification of clerodane diterpenoids from Salvia species as potential agonists at the kappa opioid receptor. Chem Biodivers. 2007;4:1586-1593.

Marek GJ, Aghajanian GK. 5-Hydroxytryptamine induced excitatory postsynaptic currents in neocortical layer $\mathrm{V}$ pyramidal cells: suppression by u-opiate receptor activation. Neuroscience. 1998;86:485-497.

McNamara P, Durso R, Brown A, Harris E. The chemistry of religiosity: evidence from patients with Parkinson's disease. In: Where God and Science Meet. How Brain and Evolutionary Studies Alter our Understanding of Religion. McNamara P ed. (Westport, USA: Praeger Publishers), pp. 1-14, 2006. 
Monte AP, Waldman SR, Marona-Lewicka D, Wainscott DB, Nelson DL, Sanders-Bush E, Nichols DE. Dihydrobenzofuran analogues of hallucinogens. 4. Mescaline derivatives. J Med Chem. 1997;40:2997-3008.

Newberg A, Waldman MR. How God changes your brain breakthrough findings from a leading neuroscientist. (New York, USA: Ballantine Books), 2010.

Nichols DE, Chemel BR. The neuropharmacology of religious experience: hallucinogens and the experience of the divine. In Where God and Science Meet How Brain and Evolutionary Studies Alter our Understanding of Religion. Vol. 3. The Psychology of Religious Experience, McNamara $\mathrm{P}$ ed. (Westport, USA: Praeger Publishers), pp. 1-33, 2006.

Nichols DE. Hallucinogens. Pharmacol Ther. 2004;101:131181.

Nolte KB, Zumwalt RE. Fatal peyote ingestion associated with Mallory-Weiss lacerations. Wester J Med. 1999;170:328.

Oken BS. Placebo effects: clinical aspects and neurobiology. Brain. 2008;131:2812-2823.

Piek T. Neurotoxins from venoms of the Hymenoptera-twenty five years of research in Amsterdam. Comp Biochem Physiol C. 1990;96:223-233.

Polsky A, Mel BW, Schiller J. Computational subunits in thin dendrites of pyramidal cells. Nat Neurosci. 2004;7:621-627.

Radosevich PM, Nash JA, Lacy DB, O'Donovan C, Williams PE, Abumrad NN. Effects of low and high intensity exercise on plasma and cerebrospinal fluid levels of ir-beta-endorphin, $\mathrm{ACTH}$, cortisol, norepinephrine and glucose in the conscious dog. Brain Res. 1989;498:89-98.

Riba J, Rodríguez-Fornells A, Barbanoj MJ. Effects of ayahuasca on sensory and sensorimotor gating in humans as measured by P50 suppression and prepulse inhibition of the startle reflex, respectively. Psychopharmacol. 2002;165:18-28.

Roberts TB. Chemical input, religious output - entheogens: apharmatheology sampler. In Where God and Science Meet How Brain and Evolutionary Studies Alter our Understanding of Religion. Vol. 3. The Psychology of Religious Experience, McNamara P ed. (Westport, USA: Praeger Publishers), pp. 235-67, 2006

Rutledge T, Reis SE, Olson M, Owens J, Kelsey SF, Pepine CJ, Mankad S, Rogers WJ, Bairey Merz CN, Sopko G, Cornell E,
Sharaf B, Matthews KA. Social networks are associated with lower mortality rates among women with suspected coronary artery disease: the National Heart, Lung and Blood Institute sponsored women's ischemia syndrome evaluation study. Psychosom Med. 2004;66:882-888.

Salak K. The Amazon's Shaman therapy. Nat Geo Adventure. March . 2006;1-4.

Seeman P, Guan HC, Hirbec H. Dopamine D2High receptors stimulated by phencyclidines, lysergic acid diethylamide, salvinorin A, and modafinil. Synapse. 2009;63:698-704.

Shulgin A, Shulgin A. Pihkal a Chemical Love Story. (CA: Transform Press), 1991.

Sjöström PJ, Häusser M. A cooperative switch determines the sign of synaptic plasticity in distal dendrites of neocortical pyramidal neurons. Neuron. 2006;51:227-238.

Smith DE, Cromy R, Downing J, Sutton L. Symposium: Psychedelic drugs and religion. J Psychedelic Drugs. 1967;1:119.

Tayebati SK, Di Tullio MA, Amenta F. Muscarinic cholinergic receptor subtypes in cerebral cortex of Fisher 344 rats: a light microscopic autoradiography study of age related changes. Mech Ageing Deve. 2006;127:115-122.

Vollenweider FX, Vontobel P, Hell D, Leenders KL. 5-HT modulation of dopamine release in basal ganglia in psilocybin induced psychosis in man a PET study with [11C]raclopride. Neuropsychopharmacol. 1999;20:424-433.

Walsh SL, Strain EC, Abreu ME, Bigelow GE. Enadoline, a selective kappa opioid agonist: comparison with butorphanol and hydromorphone in humans. Psychopharmacol. 2001;157:151-162.

Wang Z, Kai L, Day M, Ronesi J, Yin HH, Ding J, Tkatch T, Lovinger DM, Surmeier DJ. Dopaminergic control of corticostriatal long term synaptic depression in medium spiny neurons is mediated by cholinergic interneurons. Neuron. 2006;50:443-452.

Wasson RG. The Wondrous Mushroom: Mycolatry in Mesoamerica. (New York, USA: McGraw-Hill), 1980.

Zhang Y, Hamilton SE, Nathanson NM, Yan J. Decreased input specific plasticity of the auditory cortex in mice lacking M1 muscarinic acetylcholine receptors. Cerebral Cortex. 2006;16:1258-1265. 